\title{
QUALITY OF LIFE AT WORK IN A READY CARE UNIT (UPA) IN BRAZIL DURING THE COVID-19 PANDEMIC
}

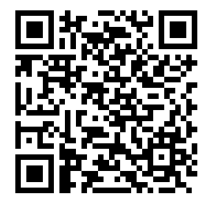

\author{
Lucas Alves de Oliveira Lima ${ }^{1}$, Paulo Lourenço Domingues Junior ${ }^{2}$, Matheus \\ Alves de Oliveira Lima ${ }^{3}$, Gabriela Halfeld Barros Duarte ${ }^{4}$ \\ 1,3,4 Graduating in Business Administration from the Federal Rural University of Rio de Janeiro \\ 2 Doctor in Sociology from the University of São Paulo and associate professor at the Federal Rural \\ University of Rio de Janeiro
}

DOI: https://doi.org/10.29121/granthaalayah.v8.i9.2020.1243

Article Type: Research Article

Article Citation: Lucas Alves de Oliveira Lima, Paulo Lourenço Domingues Junior, Matheus Alves de Oliveira Lima, and Gabriela Halfeld Barros Duarte. (2020). QUALITY OF LIFE AT WORK IN A READY CARE UNIT (UPA) IN

BRAZIL DURING THE COVID-19

PANDEMIC. International Journal of Research -GRANTHAALAYAH, 8(9), 318-327.

https://doi.org/10.29121/granthaa layah.v8.i9.2020.1243

Received Date: 20 August 2020

Accepted Date: 30 September 2020

Keywords:

Quality of Life at Work

Covid-19

Pandemic

\section{ABSTRACT}

The advent of the COVID-19 pandemic has brought about drastic changes in people's lives. In this scenario, health professionals became susceptible to acquire occupational diseases and began to have their work routine affected by the high demand for care to the infected. Therefore, this study aimed to understand the main factors that are harming the quality of life at work of professionals at a Ready Care Unit (Unidade de Pronto Atendimento - UPA) in the municipality of Três Rios/RJ during the pandemic scenario. This is an exploratory qualitative approach survey, which was conducted through a semi-structured interview with a nonprobabilistic sample of fifteen employees. For the data analysis, we resorted to discourse analysis, where it was possible to verify that the main factors that are hindering the employees are: the lack of personal protection equipment (PPE), inadequate infrastructure and the absence of training. In addition, it was also found that the employees were not infected by the new coronavirus, but most have acquired some kind of psychological problem such as insomnia, mental fatigue, excessive stress or sadness. Such diseases mainly affect women with double work hours, thus showing a greater vulnerability among female individuals.

\section{INTRODUCTION}

Infectious diseases pose a huge challenge to the world's population and result in social, economic and political impacts. In January 2020, the World Health Organization (WHO) signaled the emergence of a new coronavirus in China and in March decreed a global public health emergency with the COVID-19 pandemic. In this context, the working conditions of health professionals were aggravated by the demand for care of those infected, thus potentiating the possibility of the emergence of physical and/or mental diseases.

The new coronavirus (Sars-Cov-2) is highly contagious and has a mortality rate of around 3\%, and can cause respiratory, liver, enteric and neurological problems (ZHU et. al, 2020). In Brazil, the Ministry of Health (2020) reported that 31,700 cases of COVID-19 were confirmed among employees working against the virus until the last census held on May 14, 2020. Working conditions in the country are further aggravated by the absence of personal

(C) 2020 The Author(s). This is an open access article distributed under the terms of the Creative Commons Attribution License, which permits unrestricted use, distribution, and reproduction in any medium, provided the original author and source are credited. 
protective equipment (PPEs), lack of infrastructure, excessive workload and lack of training (RODRIGUES; SILVA, 2020).

Moreover, psychological symptoms such as depression, anxiety, stress, fatigue and panic are being noticed among health workers, factors that have contributed to impair their quality of life at work (ZHANG et. al, 2020). According to Conte (2003), there are several concepts for the expression Quality of Life at Work (QLW), but there is a consensus that the term refers to the well-being of the individual at work to the detriment of occupational diseases. Thus, the approach on the subject has never been more important than in the current pandemic scenario, given the recurrence of new contaminations and the harmful effects on mental health that include expected normal reactions of stress, as well as more serious reactions of psychic suffering.

Based on these aspects, this study aims to understand the main factors that are affecting the quality of life at work of professionals at a Three-River Ready Care Unit (UPA) during the COVID-19 pandemic. The UPA in question was founded in 2009 and, since November 2019, the services have been transferred to a campaign hospital set up by the municipal government while the unit is undergoing reform. The campaign hospital has two refrigerated tents and operates full time with emergency, low and medium complexity care. It also provides services in the medical, dental and pediatric clinical areas with laboratory tests, X-rays and electrocardiograms.

The municipality of Três Rios is located in the interior of Rio de Janeiro in the Sul-Fluminense region and has an estimated population of 81,804 (IBGE, 2019). In addition to the local residents, the city's health units serve people from surrounding regions such as Paraíba do Sul, Sapucaia, Areal, Levy Gasparian, Santana do Deserto, Chiador and others. By June 4, 2020, when the survey was completed, the city had three hundred and nineteen confirmed cases of people with COVID-19, thirteen deaths and eleven hospitalizations according to municipal data.

During the occurrence of pandemics, it is common for the efforts of the scientific community to focus on the mechanisms of pathological agents, thus neglecting the psychological implications that the phenomenon can cause among people (TUCCI et. al, 2017). Thus, this article is expected to bring contributions through the proposed analysis, which will provide theoretical and practical subsidies on the quality of life of health professionals in the face of pandemic circumstances.

\section{THEORICAL AXIS}

\subsection{HISTORICAL CONTEXT OF QUALITY OF LIFE AT WORK (QLW)}

Although the studies on Quality of Life at Work (QLW) are recent, since ancient times man has been concerned about well-being at work. In 287 BC, Arquimedes developed the Leverage Law with the objective of reducing physical effort in workers' activities. In addition, studies indicate that Euclid of Alexandria used geometric applications for the improvement of agricultural tasks in the past (MONTEIRO et. al, 2011).

However, the expression Quality of Life at Work was only used in 1950 in England. On that occasion, Eric Trist and Tavistock Institute employees created an approach whose aim was to alleviate the suffering of the workers from a restructuring of working activities (FERREIRA; ALVES; TOSTES, 2009). Thus, authors like Vieira (1993) complement that QLW has its origin in the post-war period with the implementation of the Marshall Plan in 1947 for the reconstruction of Europe.

In 1970, the topic gained a higher profile on the global stage with the structural crisis of Taylorist standards. In view of this, studies on working environment conditions began to be made frequently. Although in the Taylor era the concern was not the human side, scholars began to notice that it was necessary for the environment to become favorable for production (FERREIRA; ALVES; TOSTES, 2009). In this sense, Sant'Anna and Moraes (1998) emphasize that the humanistic perspective at work occurred from the Theory of Human Relations with the study of Elton Mayo, because until then man was seen as a machine and there was no concern for the physical and mental well-being of the employee. Thus, aspects such as recognition, personal satisfaction, self-esteem, freedom, relationship, development and among others began to be valued.

In the 1970s, research lines were developed in the United States in order to elaborate projects around QLW, highlighting the studies of the National Center for Productivity and Quality of Working Life. The works had a sociotechnical approach due to the dissatisfaction of past organizational models (MONTEIRO et. al, 2011). However, with the global energy crisis and the increase in inflation, the contributions in spite of the theme decreased. Later, in the 
Quality of Life at Work in A Ready Care Unit (Upa) in Brazil During the Covid-19 Pandemic

mid-1980s, Japan emerged in the international economic scenario in the automation sector due to models that valued employees and team spirit. With this, the U.S. government sought to match the Japanese by making investments in research and, consequently, boosting again the movements for quality of life at work (FERREIRA; ALVES; TOSTES, 2009).

Until the beginning of 1980 , some authors who were concerned with obtaining improvements in working conditions stood out, such as Nadler and Lawler; Walton; Hackman and Oldham; and Westley (FERREIRA; ALVES; TOSTES, 2009). QLW's trajectory has been through several approaches that encompass aspects such as the worker's individual perceptions of work routine; improvements in working conditions and environments; and, finally, searches for issues associated with total quality and productivity (RODRIGUES, 1991; VIEIRA, 1993; ZAVATTARO, 1999).

As for the panorama in Brazil, the actions focused on QLW began to be carried out after 1980. The pioneering studies were that of Embrapa in Brasília and the Federal Universities of Rio Grande do Sul and Minas Gerais, both influenced by international work. In the 1990s, the country gained participation in the global market and competitiveness called for organizational changes to improve the production process. As a result, scientific productions began to gain prominence (FERREIRA; ALVES; TOSTES, 2009). However, although the discussion about the theme in the country has been growing, Gonçalves, Gutierrez and Vilarta (2005, p. 86) emphasize that "the works present a more or less common theoretical-conceptual basis and the original contributions are scarce".

\subsection{CONCEPTS AND APPROACHES TO QUALITY OF LIFE AT WORK (QLW)}

Quality of life at work (QLW) is a multifaceted vision with moral, ethical and behavioural implications (LIMONGI-FRANCE, 2004). Thus, perceptions of QLW are broad and vary according to the perceptions that individuals attribute to the organizational context in which they are inserted, because people have distinct needs and each company has a culture (WHOQOL, 1994).

Based on these aspects, there are several approaches on the subject and, in a general parameter, the elucidation of the quality of life at work is situated in a range of characteristics that include aspects such as salary, stimuli to workers, recognition of effort, mutual relationship between employees/or bosses, security, issues related to health, freedom, autonomy, creativity, flexibility, working hours, infrastructure and organizational structure (CIBORRA; LANZARA, 1985).

In practice, QLW programs have, for the most part, an emphasis on occupational safety and health activities (LIMONGI-FRANÇA; ASSIS, 1995). However, Limongi-France (2004) reiterates that joint actions with a psychosocial approach should be adopted by companies. This will make it possible to achieve labour improvements through a vision that encompasses the organisation and workers as a whole.

Several authors have tried to elaborate models to measure the level of QLW in companies and, according to Monaco and Guimarães (2000), that of Walton is the most influential because it constitutes factors that go beyond the work. The Walton model (1973) presents eight categories, the first of which is called fair and adequate compensation, which refers to the prevalence of a fair remuneration at work in order to allow a dignified life for the worker. The second item is the working condition, which prioritizes the employee's well-being (physical and mental) through aspects such as workload, salubrity and adequate material resources.

According to Walton (1973), the use of capacity development is the third item, and represents the opportunities for employees to use skills and knowledge in everyday life. In this case, it involves autonomy, assignment of meaning to tasks, diversity of skills and feedback. Thus, the opportunity for growth is highlighted (fourth item) with the appreciation of the employee, career opportunities and training. In addition, the fifth item is the social integration in the organization, which is linked to the absence of marked hierarchical differences among employees.

The model also provides that there must be constitutionalism, that is, the guarantee of rights and respect for workers, the latter being the antepenultimate item cited by the author as necessary for the quality of life at work. Thus, a total space of life must prevail (seventh item) through a balance between professional and personal life, after all, time is needed for leisure and family. Finally, the last item is the social relevance of work and includes the perception of the professional (value, responsibility, image and relevance) about work.

Years later, Hackman and Oldham (1975) developed an instrument called Diagnosis of Work that highlights three important psychological factors in the dimension of work, being the knowledge of the results, responsibility for the results and the meaning of the work. These psychological states are achieved when there is an identity at 
work, variety of abilities, autonomy, feedback, understanding of the task and harmonious interpersonal relationships.

Another model often cited in the literature is that of Westley (1979), which is characterized by encompassing four essential categories of workers that can be political (job stability), psychological (self-realization), economic (wage equity) and/or sociological (participation in decisions). Furthermore, Nadler and Lawler (1983) contemplate QLW as the restructuring of work based on innovation, rewards, employee participation and improvements in the labor field.

\subsection{COVID-19 AND THE WORKING CONDITIONS OF HEALTH PROFESSIONALS IN BRAZIL}

In the work routine, health professionals are exposed to multiple risk factors due to tense work situations, which ends up making the development of physical and/or mental diseases propitious (PITTA, 1991; AQUINO, 1996). With the advent of the pandemic from COVID-19, the occupational illness of these workers was exacerbated by the demand for care of those infected and, consequently, the possibility of contagion by the new virus.

In Brazil, as in other countries, thousands of health care workers have been removed from work due to contamination by COVID-19. Data from the Ministry of Health (2020) showed that in the period from March 21 to May 14, 2020 31,700 cases were confirmed among workers in this sector nationwide. As for the numbers of suspected cases and those under analysis to date, 199,768 and 114,301 cases were registered, respectively, with $34.2 \%$ of these suspected cases being nursing auxiliaries, $16.9 \%$ nurses, $13.3 \%$ doctors and $4.3 \%$ receptionists.

As cases increase, access to personal protective equipment (PPE) for people who are on the front line to fight the virus becomes increasingly scarce. The lack of tests and equipment (masks, face protection, glasses, aprons and others) are the main difficulties in the work of Brazilian doctors, as pointed out by the Paulista Medical Association (2020) research. It is worth noting that the majority of IPEs are exported from China and, due to the lack of supply in the domestic market, their prices have increased in Brazil (MEDEIROS, 2020).

For Filho et. al (2020), the prevention measures to COVID-19 among health workers in the country are linked to biosafety with individual protection measures. However, a discussion about work conditions and organization is necessary, given the precariousness, high workload, inadequate hygiene, lack of training and lack of equipment for treatment and personal use in the face of pandemic circumstances. The working conditions are further aggravated by the occupation of patients by COVID-19 in hospitals, thus contributing to the collapse of the health system and, consequently, to the wear and tear of the employees who take care of the inmates. In Brazil, the Intensive Care Unit beds are below the target standard for the care of the population, as there are on average 15.6 Intensive Care Unit (ICU) beds for every 100 thousand people. If only the beds of the Unified Health System (SUS) are taken into consideration, the average is 7.5 (RACHE et. al, 2020).

Faced with these circumstances, there was a significant increase in mental illness among health workers during the pandemic, an illness which, according to Laurell and Noriega (1898), concerns an overload and infeasibility of psychic development. In Brazil, women are the majority among health professionals and, because of this, they are more likely to suffer from the impacts of the pandemic (UNFPA, 2020).

In a survey conducted by the Paulista Medical Association (2020), it was found that $86.6 \%$ of 2,312 doctors in the country have the perception that coworkers are depressed in their jobs due to the pandemic scenario. The Federal Nursing Council (2020) informed that an initiative of psychological support to nurses registered an average of 130 attendances per day from February to April 14. In total, 2,533 requests for help were calculated throughout Brazil, with the states that demanded the most free service being São Paulo, Minas Gerais and Rio de Janeiro, respectively.

\section{METHODOLOGY}

As far as the method is concerned, this research was characterized as an exploratory qualitative approach, which aims to understand a given phenomenon from the integrated analysis of the participants involved. Thus, processes are privileged through group or individual social actions, where all perceptions, motivations and representations of the subjects are considered (MARTINS, 2004). Such an approach has an exploratory nature and, according to Godoy (1995), it is being defined as the research develops, since the focus is the content presented by the interviewee. 
For data collection, a semi-structured interview was applied, which allows the individual to speak freely about the topic covered according to a script with previously defined questions (BONI; QUARESMA, 2005). The questions were addressed to a sample consisting of 15 professionals from a Ready Care Unit (UPA) in the municipality of Três Rios. As a requirement, only those employees who were working during the COVID-19 pandemic and who were interested in participating in the investigation were selected. Thus, convenience sampling was used, which is characterized by selection without statistical calculations and based on people's availability (OLIVEIRA, 2001).

The form was prepared by us authors and divided into two blocks, the first related to the profile of the respondents and the second linked to the quality of life at work. In the first block, the questions were closed, while in the second block they were all open. The study was based on direct interaction with those involved from an analysis based on two perspectives: the subjective, where individual perceptions are analyzed through methodological individualism; and the intersubjective, referring to the holistic view whose focus of analysis is the systems and structures (FRASER; GONDIM, 2004).

The field work took place outside the unit and, at the time of the interview, there was the use of personal protective equipment (PPE) such as masks and gloves; sanitization of materials; and, finally, the distance of two meters from those involved because of the new coronavirus. It is important to emphasize that the meetings were scheduled at intervals made available by the professionals in order not to interfere with their work. The answers were noted and, with the permission of the informants, recorded in order to obtain more precise data. The recording took an average of five minutes and all interviewees allowed this to be done.

As for data processing, we resort to the technique of discourse analysis, whose purpose is to apprehend the meaning of the word given by the subject. In this way, there is a focus on the meaning of the message and the report is explored without cuts so that there is a literal transcription of the results (VERGARA, 1997). In this research, discourse analysis took place from the selection of the text, reading of the transcripts, codification, analysis of the data and analytical writing of the discourse. The interviewees were named by fictitious name due to confidentiality and all responded promptly to the questions without any negligence or resistance.

The records took place in May 2020 for a period of fourteen days and, for the study, we contacted an employee of the unit who passed on the request to the other work colleagues. Forty-two requests were made to the professionals, of whom only fifteen agreed to participate in the investigation.

\section{RESULTS}

To analyze the main factors that are impairing the quality of life at work of professionals in a Ready Care Unit (UPA) during the COVID-19 pandemic, it was necessary to select a sample of fifteen individuals, nine women (60\%) and six men (40\%). The age groups of the interviewees ranged from 25 to 53 years, with an average age of 37 . Among the respondents, seven are nursing technicians (40\%); two are laboratory technicians (20\%); two are nurses $(13.33 \%)$; two are receptionists (13.33\%); one is a social worker (6.67\%); and, finally, one is a laboratory worker $(6.67 \%)$. Regarding the working time in the position, eight (53.33\%) have been in the institution for more than 7 years; four are between 5 and 6 years (26.67\%); and three reported to be between 1 and 2 years (20\%). Of the employees, seven are single (46.67\%), six are married (40\%); and two are divorced (13.33\%). In addition, only one man and three women reported having children

The first question was about professionals' perception of what quality of life at work is. As an answer, it was possible to verify that seven consider that it is to have available materials (for personal use and for care); five highlight aspects related to infrastructure; and three highlight good team coexistence. Thus, it is worth mentioning Ana's report, which emphasized that the quality of life at work "is to have the appropriate materials to enable good care during the COVID-19 pandemic. Without this, the efficiency of the service is compromised".

Subsequently, we seek to understand the main factors that are hampering the quality of life at work in this pandemic time. In this way, we obtained as a response from all respondents that the main factor is the lack of personal protection equipment (PPE). As this is a question with the possibility of one more answer, three people added that the precariousness of the infrastructure hinders the work routine, while one respondent highlighted the lack of training as another harmful factor. In contrast, when asked about the main aspects that help to have a better quality of life at work, it was possible to observe as an answer that nine emphasized the harmony among the team; four listed the motivation for the fact that they are working in professions that help to save lives; and two reported 
having no beneficial factors. In this sense, Kelly said the following: "I do what I love and have the thought that through my work I am contributing to saving lives.

Regarding the main impact that the COVID-19 pandemic brought to work, it was possible to observe several responses, where five reported the fear of infection by the virus; three said it was the social distancing of family members; three pointed out the physical and/or mental wear and tear; one emphasized the use of PPE; one said it was the real understanding of what it is to be a health professional; one said it is the fear of not being able to attend all patients with the virus; and one highlighted the greater care at work.

In addition, when asked if they have had any health problems from routine work in this pandemic, six of the informants said no, while nine said yes. Thus, among those who acquired it, three emphasized the emergence of stress; two became insomniac; one said he was constantly saddened; one had the onset of pneumonia; one aggravated the rhinosinusitis he already had; and one emphasized mental fatigue. It is worth noting that none of the professionals were contaminated by the new coronavirus, however, all pointed out that they had already had acquaintances who were infected, such as work colleagues, patients, friends and family. The interviewee Matheus even reported the following statement: "I had a friend with morbidities who unfortunately did not resist. It is sad to lose a loved one and not be able to do anything to help".

After that, there was an inquiry about suggestions for improvements that could be given for a better quality of life at work and, among the answers, it was possible to verify that the supply of PPE was cited six times among the employees; four emphasized the improvement in the infrastructure; two emphasized the greater appreciation; two the supply of training; one mentioned the greater reception by the coordination; and one the establishment of protocols of attendance. It is important to emphasize that each participant can expose more than one suggestion and, in this way, the results were pointed out by the number of times they were mentioned.

Finally, the last question aimed at identifying whether professionals are doing something to ensure leisure outside of work. In view of that, eight said yes, encompassing leisure activities such as watching movies and series, physical activities, cooking at home and reading books. At the end of the interview, we asked the informants to leave a report about the work routine and twelve individuals cited aspects such as increased stress, exhaustion, greater care and excessive work. Based on these aspects, Grace reported that "it's a lot of work during the pandemic, as well as being exhausting, stressful and disorganized. The other three pointed out that they are living an expected work routine of a health professional, characterizing it as normal, as we can see in João's speech: "the expected routine of a nursing technician, I try not to think too much about the disease 24 hours a day. I am trying to live life normally".

\section{ANALYSIS OF THE RESULTS}

Through the data, it was possible to observe in the sample a preponderance of female individuals (60\%). This fact evidenced in this research is not an isolated case of the institution, since data from the United Nations Population Fund (2020) indicate that there is a predominance of women in the health sector in Brazil and, consequently, in the front line in combating the new coronavirus. Thus, they are more susceptible to COVID-19 contagion because they are the majority of the workforce in the unit.

The Three Rivers Ready Care Unit (UPA) was created in 2009 and, in this way, it can be seen that the employees are mostly in the position since the inauguration of the unit, since they are in the organization for more than seven years. Moreover, the youngest person in the organization is 25 years old, which shows that there are few young people inserted in the place.

Respondents to this survey have two perspectives on what it is like to have quality of life at work, and they are related to proper working conditions (provision of materials and infrastructure) and good interpersonal relationships. These are two categories provided for in the Walton model (1973) that are necessary for occupational well-being. Thus, perceptions constitute the attributions that workers give to the labour context in which they are inserted, encompassing the culture, expectations, values, standards and concerns existing in this pandemic scenario.

However, it was possible to observe that in practice these elements are not being fully experienced by the employees, since the main factors that are harming the quality of life at UPA are the lack of personal protection equipment (PPE), inadequate infrastructure and the absence of training. Currently, the professionals are working in a temporary campaign hospital with two makeshift tents, which worsens working conditions in a context where the demand for care is exacerbated by the spread of the new coronavirus. Furthermore, the lack of equipment for individual protection and training contribute exponentially to the possibility of contagion by COVID-19, since the 
Quality of Life at Work in A Ready Care Unit (Upa) in Brazil During the Covid-19 Pandemic

servers are exposed to the risk of infection by this highly contagious virus without the preparation and use of appropriate equipment. As seen in the theoretical axis, this situation is faced throughout the country, which has been hampered by the lack of supply in the national market due to the increase in prices and the dependence on IPEs from China (MEDEIROS, 2020).

However, despite the obstacles to performing the tasks, it appears that the respondents did not contract the new coronavirus, but all reported having some acquaintance who was infected. Thus, the main impact of the pandemic on workers' routines was the fear of infection with the virus. Besides living with this tension, professionals also deal with the fear of contaminating relatives and, because of this, some have opted for social distancing from loved ones. Based on these aspects, authors such as Shigemura et. al (2020) point out that fear of contagion can potentiate dysphoric states of mind, highlighting what was seen in this research, where most of the interviewees acquired some psychological problem due to routine work. Thus, fear, which is a necessary defense component for possible threats, has become chronic and therefore harmful to these people.

These problems include excessive stress, sadness, insomnia and mental fatigue. These diseases mainly affect women in the unit who have children and are married, thus demonstrating a greater vulnerability among the female gender which constitutes a double work day. With the measures of social isolation, women who manage the domestic routine and work end up being overloaded and, consequently, susceptible to illness. In view of this, it can be seen that the impacts of the pandemic affect everyone in general, however, they are not manifested in the same proportion in the various social groups and classes.

At UPA, interviewees already suffer from mental fatigue, but without a vaccine for Sars-Cov-2, wear and tear can become prolonged and cause more serious problems such as depersonalization, cardiovascular disease and musculoskeletal disorders. In the current pandemic scenario, the transmission of the virus occurs rapidly around the world, thus affecting the work routine of health professionals.

To deal with work problems, employees seek to perform leisure activities. It is important to emphasize that beneficial factors such as harmonic team and love for the profession help people to have a better quality of life in the unit. This way, there is a social integration in the organization, corroborating what the Walton (1973) model foresees. In this context, the group acts in a synergic way focusing the efforts to provide services through mutual agreements and good coexistence with the other employees. Consequently, equality among professionals will prevail, thus contributing to the elimination of hierarchical barriers and discriminatory aspects.

As for suggestions for improvement, the most cited aspects were the availability of personal protective equipment (PPE) and better infrastructure. Thus, it is noted that there is a concern around the supply of materials, because unlike what occurs in a factory where the lack of resources makes production impossible, in the public health sector workers are dealing with human lives. Moreover, the infrastructure has an active participation to achieve effective results and, therefore, it is impossible to think about QLW without an adequate place to carry out the activities.

\section{CONCLUSION}

Through this qualitative research, it was possible to conclude that the lack of IPEs, inadequate infrastructure and lack of training are the main factors that are affecting the quality of life at work of the professionals at the Três Rios Emergency Unit (UPA) during the COVID-19 pandemic. Thus, the high demand for patient care and the fear of exposure to the new coronavirus cause greater pressure on the work routine and, consequently, cause the worsening and manifestation of psychological diseases. Such manifestations mainly affect women who have a double workday and, despite the lack of materials, the interviewees were not infected by Sars-Cov- 2 .

Depending on the above, the routine at the institution has been stressful and the servers point out suggestions for improvements related to the main difficulties faced by the unit, such as the provision of PPE and a better infrastructure. Therefore, it was possible to verify the fear of professionals to contaminate themselves and take the virus to their place of residence.

In addition, it is noted that workers' perceptions of QLW are related to adequate working conditions and good interpersonal relations. In practice, the respondents emphasize the group's harmony as a beneficial factor for QLW and, in this way, it is evident the joint thinking of the members about good interpersonal relationships. In this perspective, the notion of synergy indirectly prevails to avoid more serious illnesses and contributes for the staff to focus their efforts on fighting OVID-19. 
Therefore, it is perceived that health professionals face several impasses for service delivery in the current pandemic landscape. Thus, actions related to biosafety and full working conditions are necessary. Thus, it will be possible to take a clinical look at employee protection and minimize the risks of contamination by the new coronavirus. In addition, the application of ergonomic methods through two axes stands out: working condition, sometimes associated with aspects of infrastructure; and clinical activity, referring to the study of subjectivity at work to seek to offer emotional support to workers through psychologists.

\section{SOURCES OF FUNDING}

This research received no specific grant from any funding agency in the public, commercial, or not-for-profit sectors.

\section{CONFLICT OF INTEREST}

The author have declared that no competing interests exist.

\section{ACKNOWLEDGMENT}

None.

\section{REFERENCES}

[1] AGÊNCIA BRASIL. Ministério da Saúde: 31 mil profissionais da saúde já foram infectados pelo novo coronavírus no Brasil. Disponível em: <https://agenciabrasil.ebc.com.br/saude/noticia/2020-05/no-brasil31790-profissionais-de-saude-contrairam-covid-19> Access on 7 maio, 2020.

[2] AQUINO, E. M. L. Gênero, trabalho e hipertensão arterial: um estudo de trabalhadoras em enfermagem em Salvador/Ba. [tese de doutoramento]. Salvador (BA): Instituto de Saúde Coletiva, Universidade Federal da Bahia; 1996.

[3] ASSOCIAÇÃO PAULISTA DE MEDICINA. Médicos apontam faltas de testes e EPIs como principal problema no combate à pandemia. Disponível em: <http://associacaopaulistamedicina.org.br/noticia/medicos-apontamfalta-de-testes-e-epis-como-principal-problema-no-combate-a-pandemia> Access on 9 maio, 2020.

[4] BONI, V.; QUARESMA, J. L. Aprendendo a Entrevistar: como fazer entrevistas em Ciências Sociais. Florianópolis: Revista Em Tese, v. 2, n. 1, p. 68-80, 2005.

[5] CIBORRA, C.; LANZARA, G. F. Progettazione delle Tecnologie e Qualita del Lavoro. Milão: Franco Angeli Editore, 330 pp., 1985.

[6] COFEN. Canal de apoio atende média de 130 profissionais de enfermagem por dia. Disponível: <http://www.cofen.gov.br/canal-de-apoio-atende-media-de-130-profissionais-de-enfermagem-pordia_79375.html> Access on 10 maio, 2020.

[7] CONTE, A. L. Qualidade de vida no trabalho. Curitiba: Revista FAE BUSINESS, n. 7, nov., p. 32-32, 2003.

[8] FERREIRA, M. C.; ALVES, L.; TOSTES, N. Gestão de qualidade de vida no trabalho (QVT) no serviço público federal: o descompasso entre problemas e práticas gerenciais. Brasília: Psicologia - Teoria e Pesquisa, v. 25, n. 3, p. 319-327, 2009.

[9] FRASER, M. T. D.; GONDIM, S. M. G. Da fala do outro ao texto negociado: discussões sobre a entrevista na pesquisa qualitativa. Ribeirão Preto: Paidéia, 2004.

[10] FILHO, J. M. K. et. al. A saúde do trabalhador e o enfrentamento da COVID-19. São Paulo: Rev. bras. sau. ocup., 2020.

[11] GODOY, A. S. Pesquisa qualitativa: Tipos Fundamentais. São Paulo: Revista de Administração de Empresas, v. 35, n. 3, p. 20-29, 1995.

[12] GONÇALVES, A.; GUTIERREZ, G. L.; VILARTA, R. Gestão da qualidade de vida na empresa. Campinas: ed. IPES, 2005. 
Quality of Life at Work in A Ready Care Unit (Upa) in Brazil During the Covid-19 Pandemic

[13] HACKMAN, J. R.; OLDHAM, G. R. Development of the Job Diagnostic Survey. Journal of Applied Psychology. vol. 60, no. 2, 159-170, 1975.

[14] IBGE. População no último censo. 2019. Disponível em: <https://cidades.ibge.gov.br/brasil/rj/tresrios/panorama>. Access on 5 maio, 2020.

[15] LAURELL, A. C.; NORIEGA, M. Processo de produção e saúde: trabalho e desgaste operário. São Paulo: Hucitec; 1989.

[16] LIMONGI-FRANÇA, A. C. Qualidade de Vida no Trabalho - QVT: Conceitos e práticas da sociedade pósindustrial. São Paulo: Atlas, 2 ed., 2004.

[17] LIMONGI-FRANÇA, A. C.; ASSIS M. P. Stress projetos de qualidade de vida no trabalho:caminhos percorridos e desafios. São Paulo: ERA light, mar/abr., v.2, n.2. p.26-32, 1995.

[18] MARTINS, H. H. T. S. Metodologia qualitativa de pesquisas. São Paulo: Educação e Pesquisa, n.2, p. 289-300, maio/ago., 2004.

[19] MEDEIROS, E. A. S. A luta dos profissionais da saúde no enfrentamento da COVID-19. São Paulo: Acta Paul Enferm., p. 1-4, 2020.

[20] MÔNACO, F.; GUIMARÃES, V. N. Gestão da qualidade total e de vida no trabalho: o caso da gerência da administração dos correios. São Paulo: RAC, v.4, n.3, set./dez., p.67-68, 2000.

[21] MOREIRA, E. M. A. et. al. O impacto da qualidade de vida no trabalho (QVT) no faturamento das indústrias metalúrgicas do Estado do Pará. Ponta Grossa: Revista de Administração da UEPG, v. 2, n. 1, p. 18-33, 2011.

[22] NADLER, D. A.; LAWLER, E. E. Quality of work life: perspectives and directions. Organizational Dynamics, v. 11, n. 3, p. 20-30, 1983.

[23] OLIVEIRA, T. M. V. Amostragem não probabilística: adequação de situações para uso e limitações de amostras por conveniência, julgamento e quotas. Rev Adm On Line, jul/ago/set.; 2(3), 2001.

[24] PITTA, A. Hospital: dor e morte como ofício. São Paulo (SP): Editora Hucitec; 1991.

[25] RACHE, B. et. al. Necessidades de infraestrutura do SUS em preparo ao COVID-19: Leitos de UTI, respiradores e ocupação hospitalar. Rio de Janeiro: Instituto de Estudos para Políticas de Saúde, n. 3, 2020.

[26] RODRIGUES, M. C. V. Qualidade de vida no trabalho: evolução e análise no nível gerencial. Fortaleza: Fundação Edson Queiroz (Mimeo), 1991.

[27] RODRIGUES, N. H.; SILVA, L. G. A. Gestão da pandemia Coronavírus em um hospital: relato de experiência profissional. Pelotas: J. nurs. health. (n.esp.):e20104004, 2020.

[28] SANT'ANNA, A. S.; MORAES, L. F. R. 0 movimento da qualidade de vida no trabalho: um estudo de suas origens, evolução, principais abordagens e avanços no Brasil. Belo Horizonte: CEPEAD - UFMG, 1998.

[29] SHIGEMURA, J. et. al. Public responses to the novel 2019 coronavirus (2019-nCoV) in Japan: mental health consequences and target populations. Psychiatry and Clinical Neurosciences, 2020.

[30] TRÊS RIOS. Prefeitura de Três Rios amplia os repasses mensais para o Hospital de Clínicas Nossa Senhora da Conceição. Disponível em: <http://www.tresrios.rj.gov.br/noticia/prefeitura-de-tres-rios-amplia-osrepasses-mensais-para-o-hospital-de-clinicas-nossa-senhora-daconc\#: :text=Atualmente\%2C\%20o\%20hospital\%20conta\%20com,SUS\%20e\%20quatro\%20para\%20con v\%C3\%AAnios.> Access on 3 maio, 2020.

[31] TRÊS RIOS. Prefeitura de Três Rios, após 10 anos de atendimentos, inicia a reforma da UPA e transfere atendimentos para hospital de campanha. Disponível em: <http://www.tresrios.rj.gov.br/noticia/prefeiturade-tres-rios-apos-10-anos-de-atendimentos-inicia-a-reforma-da-upa-e-transfere-atendimento> Access on 7 May, 2020.

[32] TUCCI, V. et. al. The forgotten plague: psychiatric manifestations of ebola, zika, and emerging infectious diseases. Philadelphia: J Glob Infect Dis., 9:151-6, 2017.

[33] FUNDO DE POPULAÇÃO DAS NAÇÕES UNIDAS (UNFPA). Pandemia de COVID-19. Disponível em: $<$ https://brazil.unfpa.org/pt-br/pandemia-de-covid-19> Access on 8 maio, 2020.

[34] VERGARA, S. C. Métodos de pesquisa em administração. São Paulo: Atlas, 1997.

[35] VIEIRA, D. F. V. B. Qualidade de Vida no Trabalho dos Enfermeiros em Hospital de Ensino. Dissertação de mestrado. Programa de Pós-Graduação em Administração. Universidade Federal do Rio Grande do Sul, Porto Alegre. 169 pp., 1993.

[36] WALTON, R. E. Quality of working of life: What is it? Cambridge: Slow Management Review, v. 15, n. 1, p. 1121, 1973.

[37] WESTLEY, W. A. Problems and Solutions in the Quality of Working Life. Human Relations. 32, 113 - 123, 1979. International Journal of Research -GRANTHAALAYAH 
[38] WHOQOL Group. The development of the World Health Organization quality of life assessment instrument (WHOQOL). In: ORLEY, J.; KUYKEN, W. (Eds.). Quality of life assessment: international perspectives. Heidelberg: Springer, p.41-60, 1994.

[39] WORLD HEALTH ORGANIZATION (OMS). WHO Director-General's opening address at the media briefing on OVID-19 - 11 March 2020. Available at: https://www.who.int/dg/speeches/detail/who-director-general-sopening-remarks-at-the-media-briefing-on-covid-19---11-march-2020> Access on 7 May, 2020.

[40] ZAVATTARO, H. A. A Qualidade de Vida no Trabalho de Profissionais da Área de Informática: um Estudo Exploratório. Dissertação de mestrado. Instituto de Psicologia, USP, São Paulo, 1999.

[41] ZHANG, J. et. al. Recommended psychological crisis intervention response to the 2019 novel coronavirus pneumonia outbreak in China: A model of West China Hospital. China: Precision Clinical Medicine,3(1), 3-8, 2020.

[42] ZHU, N. et. al. A novel Coronavirus from patients with pneumonia in China. The new england journal of medicine, 2020. 